\title{
Nonlinear Time History Analysis of Anti Seismic Device on Highway Bridges
}

\author{
M. Firman Jauhari, Arie Febry Fardheny and Dr. Eng. Irfan Prasetia \\ Magister Study Program of Civil Engineering, Lambung Mangkurat University, Indonesia \\ Lambung Mangkurat University, Indonesia \\ Indonesia
}

\begin{abstract}
There are many earthquake suppression technologies offered by experts, one of them is the use of Lead Rubber Bearing (LRB) in civil buildings. LRB works by reducing the dynamic load acting on a bridge caused by seismic loads. It diverts the load that works through the dynamic system by maintaining a balance between the force and displacement that occurs. The purpose of this study is to find out how much influence are the use of LRB on the reduction of seismic loads received by a flyover. This study compares the structure of the highway bridge using LRB to those non- $L R B$, where the results show that the use of LRB can reduce the base shear occurs in bridge piers and is able to increase energy attenuation, but causes additional displacement and acceleration.
\end{abstract}

Key word: Lead Rubber Bearing (LRB), Time history, Base shear, Displacement, Acceleration.

\section{INTRODUCTION}

An earthquake is a recurring geological event that becomes a serious problem in many countries. An earthquake with a destructive force can cause many losses such as fatalities, damaged infrastructure, loss of material, stalled economy and so on (Park and Hamza, 2018). Therefore, anticipatory measures are needed to reduce the adverse effects of these natural events, one of which is to build earthquake-resistant building structures.

One application of earthquake resistant structures is to install anti-seismic devices on the structure. In its application, one way to anticipate adverse effects caused by earthquakes on building structures is to install anti-seismic devices. The working principle of anti-seismic device is to separate the movement of the super structure and the sub structure due to horizontal forces caused by the earthquake load so that the movement of the soil distributed by the sub structure can be muted in such way as to reduce its destructive power to the super structure (Dezfuli, et al, 2016) (Himeno, 2018). One of the most common anti-seismic devices used today is the earthquake resistant rubber bearing Lead Rubber Bearing (LRB). LRB is a rubber bearing designed from rubber combined with steel plates and a lead core placed in the middle of the bearing, in order to make the LRB has high damping capability, horizontal flexibility and very rigid in the vertical direction, which is why LRB is strong enough to withstand the vertical loads that burden it and able to reduce earthquake forces that occur. (Buckle, et al. 2006) (Naeim and Kelly, 1999) (Nuraini, et al. 2018). The LRB's profile can be seen in Figure 1.

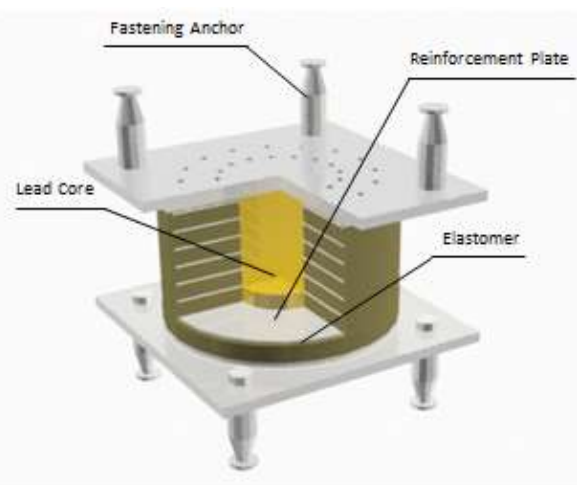

Figure 1. Lead Rubber Bearing 
Nowadays, there are many companies that produce LRB, all of which claim that their products are able to reduce the earthquake load that works. Based on these claims, this research was conducted to find out how much influence the use of LRB on reducing the seismic load received by the bridge structure and to determine the behavior of the LRB when the seismic load works.

This research was carried out by comparing the condition of the bridge structure models without using LRB with the bridge structure using LRB using the finite element method in order to analyze the effect of using the tool on structural response and evaluating how much the effectiveness of its use on the strength of the bridge that received seismic loads.

\section{RESEARCH METHODS}

In this study, the bridge structure to be reviewed is a highway type bridge, where the lower building uses a single pier with the upper building structure using a type I concrete girder beam. The perspective image and profile of the bridge can be seen in Figure 2.
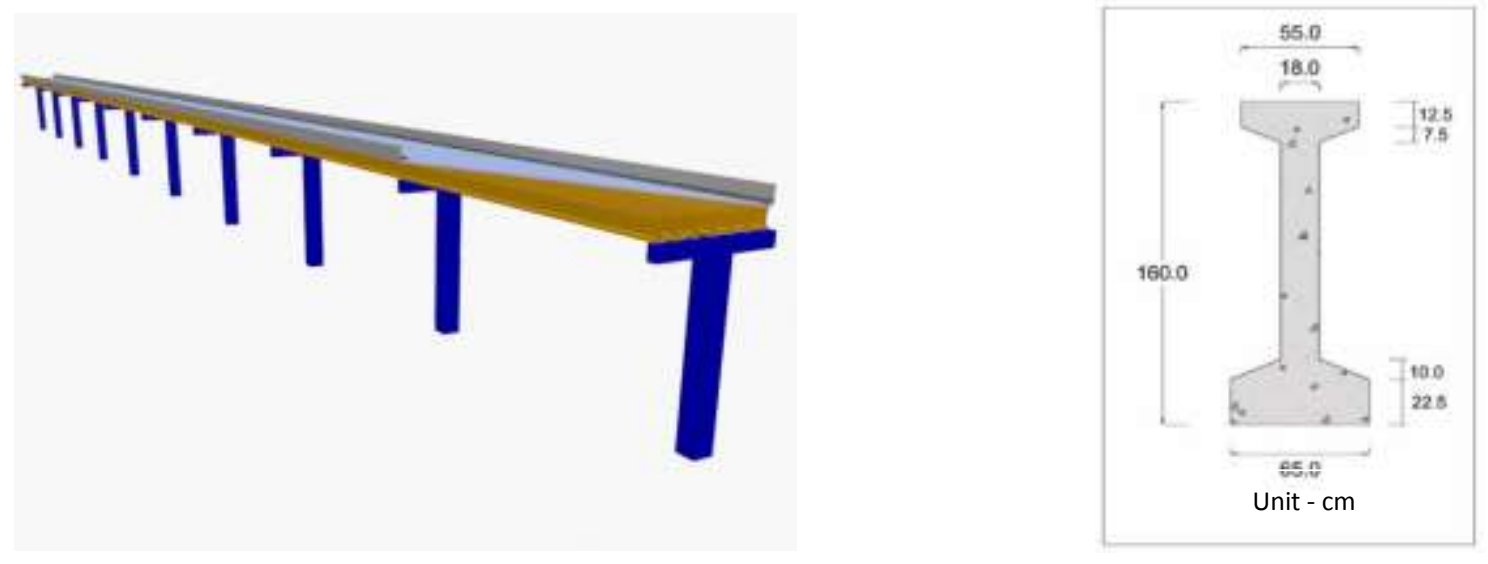

Figure 2. Perspective and profile of girders

The dimensions of the bridge structure elements used are as follows:

1. Total bridge span $=270 \mathrm{M}$

2. Spread between piers $=30 \mathrm{M}$

3. Bridge Height $=14 \mathrm{M}$

4. Number of girder beams $=7$ pieces

5. Profile girder beam I, (Figure III.1) K quality of concrete $=500 \mathrm{~kg} / \mathrm{cm}^{2}$

6. Transverse girder $0.5 \times 0.8 \times 8.4$ concrete quality $\mathrm{K}=350 \mathrm{~kg} / \mathrm{cm}^{2}$

7. Pier bridge, $1.6 \times 1.6 \times 14$ concrete quality $\mathrm{K}=350 \mathrm{~kg} / \mathrm{cm}^{2}$

Loading for bridges is calculated based on SNI 1725-2016. The loads that work on bridges are as follows: Dead Load, additional dead load, live load.

In this study the bridge structure will be burdened with earthquake load with the response spectrum method and time history analysis method. Where in the Time History analysis, 3 artificial ground motion data obtained from seismo artif software will be used.

\section{STAGES OF ANALYSIS}

In this study the analysis was carried out using the finite element analysis method where the data in the form of a girder beam, base type LRB isolator, transverse beam, piers and loading were used according to the initial data to be used. Then the structure is analyzed by the earthquake load planned previously, to get a dynamic response from the structure. Following is the explanation of the stages of analysis:

1. Collection of data needed to analyze bridge structures, such as: bridge layout, dimensions of bridge structure, loading, and earthquake data to be used.

2. Calculating response spectrum plans from regions that will be reviewed based on SNI 2833-2016.

3. For time history data, in this study using 3 artificial ground motion data obtained from Seismo Artif software.

4. Determine the LRB property to be used based on the Vmaximum and earthquake building on the bridge by taking the initial reference from the LRB's product catalog (ISOSISM-Freyssinet product catalog, 2017) 
International Journal of Advances in Scientific Research and Engineering (ijasre), Vol 6 (6), June -2020

5. Evaluation of the base shear force and displacement that occurs in the LRB property selected for earthquake loads with response spectrum analysis and analysis of time history.

6. If it is fulfilled, then it can proceed to the next step, but if it does not fulfill it, a LRB property will be re-calculated by trial and error method, using the initial LRB property as a reference.

7. Analyze structural responses to the effects of LRB use.

8. Conclusion

\section{RESULTS AND DISCUSSION}

To ease the analysis process, the bridge structure was modeled using only 2 girder beams where the LRB performance in the middle pier will be used as material for research.

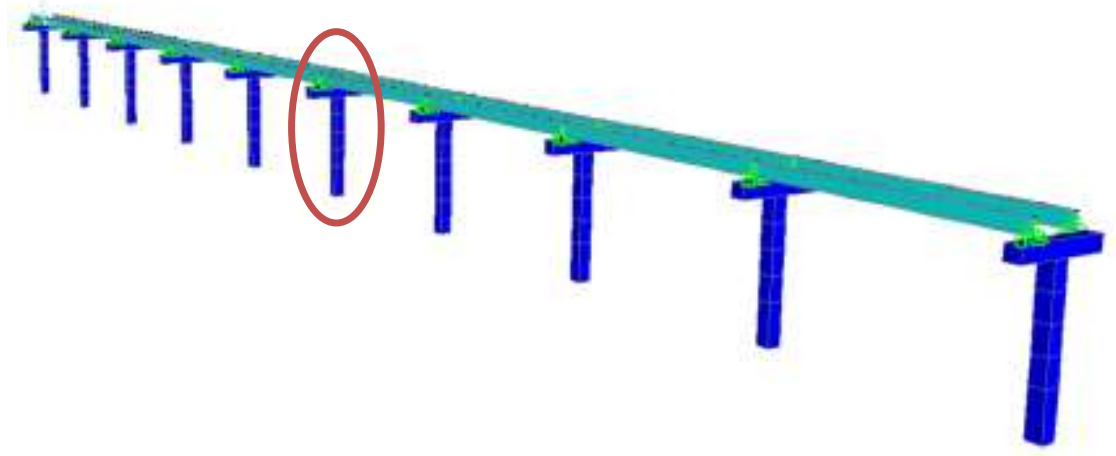

Figure 3. The location to be reviewed on the bridge

\subsection{TIME HISTORY}

In accordance with SNI 2833-2016, for the method of calculating structures subject to dynamic loads using a time history analysis, a minimum is required for 3 real ground motion recordings. Of the 3 real ground motion recordings, the highest value was taken.

In this study using artificial ground motion obtained by using the data from Seismosoft's Seismo Artif software. This method is done by involves spectrum matching using wavelets using wavelet algorithm proposed by Abrahamson, 1992 and Hancock et al., 2006 (Samanta and Pandey, 2017).
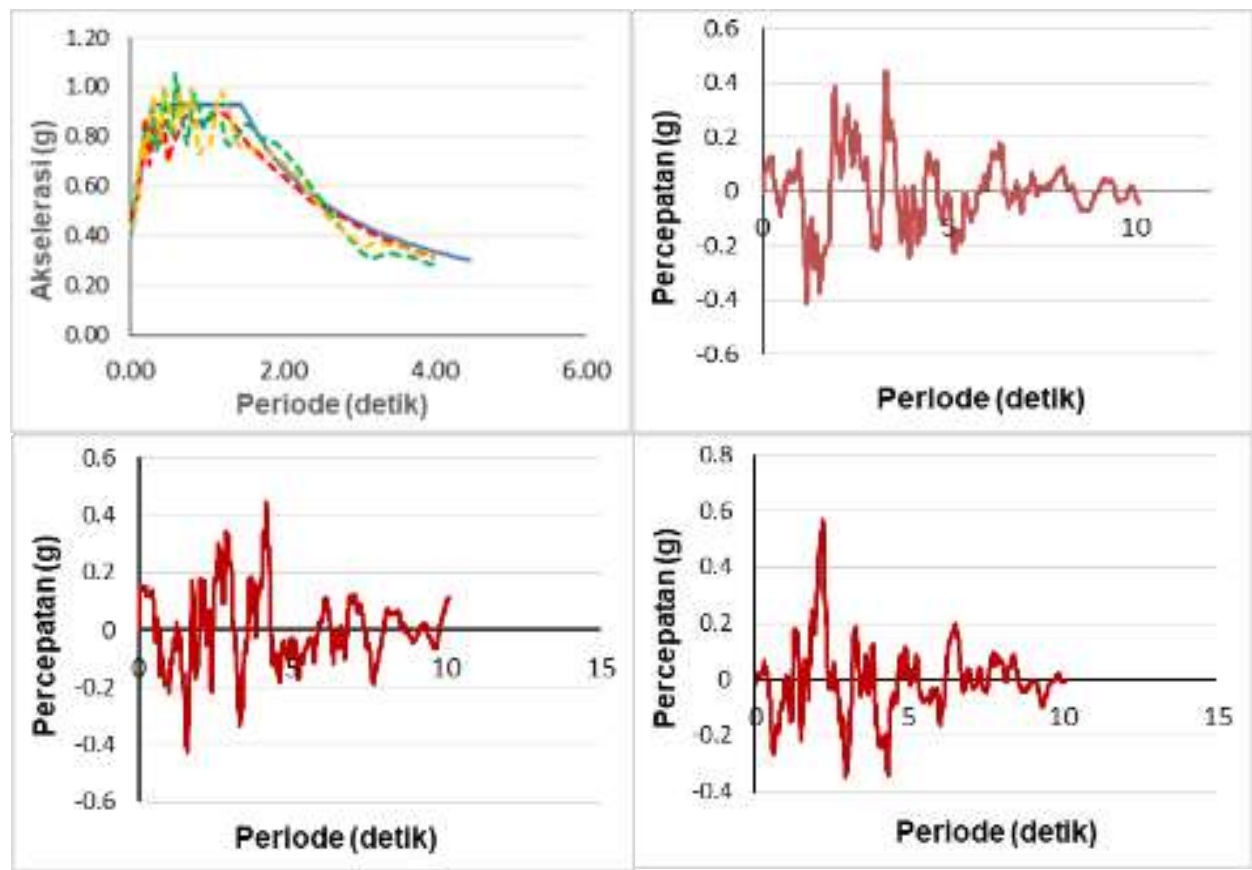

Figure 4. Artificial ground motion

In Figure 4 it can be seen that the response spectrum of the soft soil at PGA $=0.446 \mathrm{~g}, \mathrm{Ss}=1.031 \mathrm{~g}$, and $\mathrm{SI}=0.567 \mathrm{~g}$, obtains the peak surface acceleration in a period of 0.293 seconds with an acceleration value of $0.928 \mathrm{~g}$, and then begins to 
decrease in the period of 1.467 seconds. From the plan's response spectrum data, Artificial ground motion was obtained using seismo artif software. Peak ground motion is at $1.05 \mathrm{~g}$ and the main ground motion time period occurs at a time period of 0.293 seconds to 1.467 seconds.

\subsection{LRB PLANNING}

Determination of the initial LRB property is carried out using a vertical load value, where the LRB must be able to with stand vertical loads above it before receiving earthquake loads.

Vertical load acting on LRB :

- Vertical Load D = $151 \mathrm{KN}$

- Vertical Load Max (strong 1) = $263 \mathrm{KN}$

- VEarthquake $=446 \mathrm{KN}$

For the initial reference type of LRB to be used, the type of LRB is taken from the ISOSISM-Freyssinet product catalog with reference to the value of vertical load.

Table 1. LRB's product catalog (ISOSISM - Freyssinet, 2017)

\begin{tabular}{|c|c|c|c|c|c|c|c|c|c|c|}
\hline \multirow[b]{2}{*}{$\begin{array}{c}\varnothing \\
\mathrm{mm}\end{array}$} & \multirow[b]{2}{*}{$\begin{array}{l}T_{r} \\
\mathrm{~mm}\end{array}$} & \multicolumn{9}{|c|}{ LRB $0,4=10$} \\
\hline & & $\begin{array}{c}\mathrm{H} \\
\mathrm{mm}\end{array}$ & $\begin{array}{r}\Delta_{\max } \\
\mathrm{mm} \\
\end{array}$ & $\begin{array}{c}V_{\max } \\
\mathrm{kN}\end{array}$ & $\begin{array}{c}V_{\text {seism }} \\
\text { kN }\end{array}$ & $\begin{array}{c}K_{r} \\
\mathrm{kN} / \mathrm{mm}\end{array}$ & $\begin{array}{c}K_{i p} \\
\mathrm{kN} / \mathrm{mm}\end{array}$ & $\begin{array}{r}F_{y} \\
\mathrm{kN} \\
\end{array}$ & $\begin{array}{c}K_{e f f} \\
\mathrm{kN} / \mathrm{mm}\end{array}$ & $\begin{array}{c}\xi_{\text {eff }} \\
\%\end{array}$ \\
\hline$\varnothing 300$ & 45 & 129 & 110 & 1430 & 820 & 0,59 & 5,89 & 34 & 0,87 & 26 \\
\hline$\varnothing 300$ & 70 & 169 & 170 & 920 & 290 & 0,38 & 3,79 & 34 & 0,56 & 26 \\
\hline$\varnothing 350$ & 55 & 145 & 135 & 2200 & 1230 & 0,65 & 6,53 & 49 & 0,98 & 27 \\
\hline$\varnothing 350$ & 75 & 177 & 185 & 1610 & 600 & 0,48 & 4,79 & 49 & 0,72 & 27 \\
\hline$\varnothing 400$ & 60 & 147 & 150 & 2870 & 1670 & 0,79 & 7,85 & 60 & 1,15 & 26 \\
\hline$\varnothing 400$ & 90 & 192 & 225 & 1950 & 630 & 0,52 & 5,24 & 60 & 0,77 & 26 \\
\hline$\varnothing 450$ & 72 & 165 & 180 & 3940 & 2180 & 0,83 & 8,26 & 80 & 1,23 & 27 \\
\hline$\varnothing 450$ & 108 & 219 & 260 & 2620 & 770 & 0,55 & 5,51 & 80 & 0,83 & 27 \\
\hline$\varnothing 500$ & 84 & 197 & 210 & 4380 & 2360 & 0,87 & 8,67 & 110 & 1,34 & 28 \\
\hline$\varnothing 500$ & 126 & 257 & 290 & 2920 & 870 & 0,58 & 5,78 & 110 & 0,92 & 29 \\
\hline$\varnothing 550$ & 88 & 198 & 220 & 5460 & 3050 & 1,01 & 10,10 & 119 & 1,50 & 27 \\
\hline$\varnothing 550$ & 144 & 275 & 320 & 3360 & 1000 & 0,62 & 6,17 & 119 & 0,95 & 28 \\
\hline
\end{tabular}

After determining the type of LRB to be used, then the LRB property is analyzed with response spectrum and time history to determine the base shear and displacement that occur due to the use of LRB on the bridge structure. The results of checking LRB properties with modeling are as follows :

Table 2. Base shear force results from response spectrum non-LRB

\begin{tabular}{|c|c|c|c|}
\hline Load & $\begin{array}{c}\boldsymbol{F x} \\
(\boldsymbol{k N})\end{array}$ & $\begin{array}{c}\boldsymbol{F y} \\
(\boldsymbol{k N})\end{array}$ & $\begin{array}{c}\boldsymbol{F z} \\
(\boldsymbol{k} \boldsymbol{N})\end{array}$ \\
\hline$R S x$ & 1867 & 663 & - \\
$R S y$ & 552 & 2213 & - \\
\hline
\end{tabular}

Table 3. Base shear force results from response spectrum $L R B$

\begin{tabular}{|c|c|c|c|}
\hline Load & $\begin{array}{c}\boldsymbol{F x} \\
(\boldsymbol{k N})\end{array}$ & $\begin{array}{c}\boldsymbol{F y} \\
(\boldsymbol{k N})\end{array}$ & $\begin{array}{c}\boldsymbol{F z} \\
(\boldsymbol{k N})\end{array}$ \\
\hline$R S x$ & 1968 & 632 & - \\
$R S y$ & 584 & 2210 & - \\
\hline
\end{tabular}

Table 4. Displacement that occurs in LRB with response spectrum

\begin{tabular}{|c|c|c|c|c|c|}
\hline Sumbu & $\begin{array}{c}\text { Top LRB } \\
(\mathbf{m m})\end{array}$ & $\begin{array}{c}\text { Bottom LRB } \\
(\mathbf{m m})\end{array}$ & $\begin{array}{c}\text { Dmax } \\
(\mathbf{m m})\end{array}$ & $\begin{array}{c}\text { Top - Bottom } \\
(\mathbf{m m})\end{array}$ & Annotation \\
\hline X & 303 & 297 & 185 & 6 & fulfill \\
Y & 310 & 304 & 185 & 6 & fulfill \\
\hline
\end{tabular}

If the base shear that occurs from the results of response spectrum nonLRB with response spectrum LRB is compared as seen in Table IV.2. and Table IV.3. it can be seen that the use of LRB does not have a large effect on the strength of the bridge structure then it needs to be re-calculated property of LRB even though the displacement value that occurs is smaller than Dmax. 
International Journal of Advances in Scientific Research and Engineering (ijasre), Vol 6 (6), June -2020

To redesign the LRB property, this study used a trial and error method using time history analysis. Where the initial property of the LRB is a reference in determining the next LRB property by setting the maximum displacement that occurs at 185 $\mathrm{mm}$.

Table 5. Recapitulation of trial and error LRB property result

\begin{tabular}{|c|c|c|c|c|c|c|}
\hline $\begin{array}{c}\text { No. } \\
\text { Property }\end{array}$ & $\begin{array}{c}\text { Dmax } \\
(\mathbf{m m})\end{array}$ & $\begin{array}{c}\boldsymbol{F y} \\
(\boldsymbol{k N})\end{array}$ & $\begin{array}{c}\boldsymbol{K}_{\boldsymbol{i p}} \\
(\boldsymbol{k N} / \mathbf{m m})\end{array}$ & $\begin{array}{c}\boldsymbol{K}_{\text {eff }} \\
(\boldsymbol{k N} / \mathbf{m m})\end{array}$ & $\begin{array}{c}\text { Base shear } \\
(\boldsymbol{k N})\end{array}$ & $\begin{array}{c}\boldsymbol{D} \\
(\mathbf{m m})\end{array}$ \\
\hline 1. & 185 & 49 & 4.79 & 9.63 & 63553.56 & 329.243 \\
2. & 185 & 80 & 4.79 & 0.72 & 70512.433 & 1246.7 \\
3. & 185 & 49 & 8.16 & 0.72 & 87334.198 & -52.81 \\
4. & 185 & 80 & 4.79 & 8.19 & 61177.928 & 150.677 \\
5. & 185 & 49 & 8.16 & 8.19 & 70943.404 & 175.981 \\
\hline
\end{tabular}

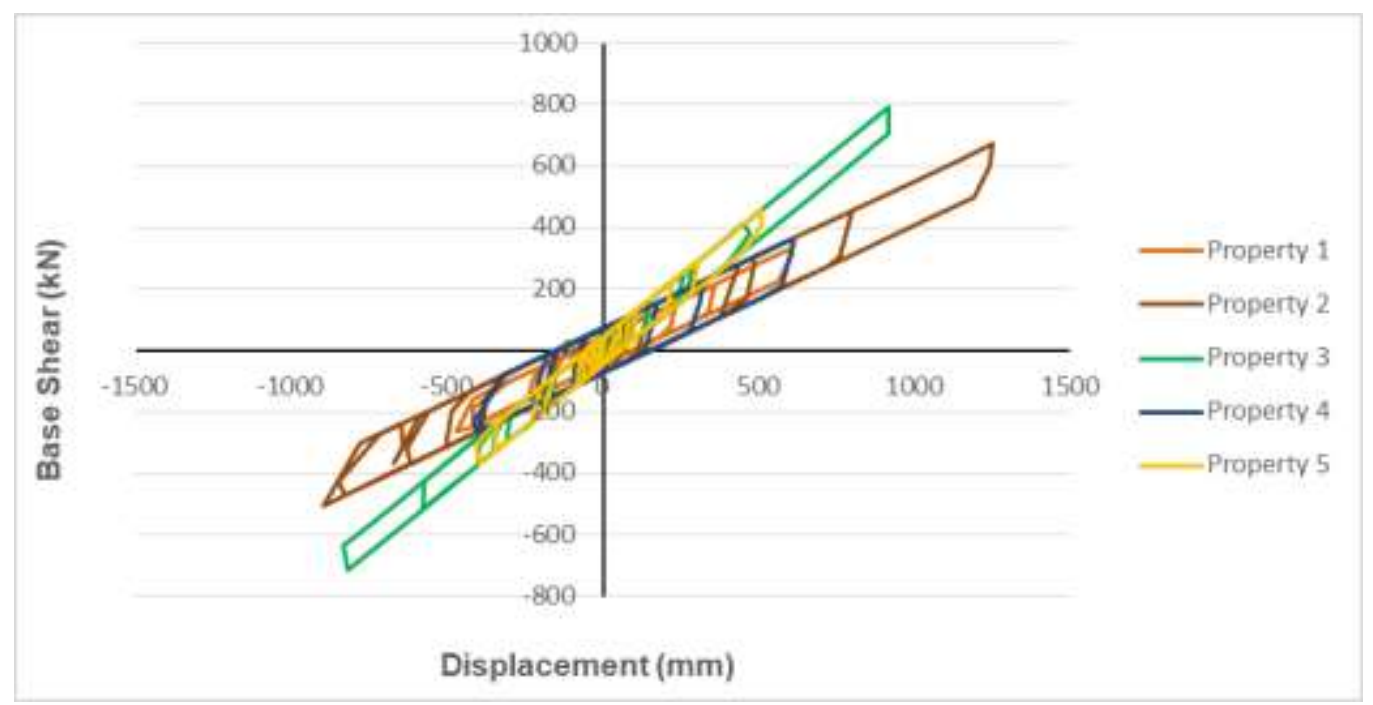

Figure 6. Graph of Base Shear recapitulation of trial and error LRB property result

Table 6. Base shear force time history results without LRB

\begin{tabular}{|c|c|c|c|}
\hline Load & $\begin{array}{c}\boldsymbol{F x} \\
(\boldsymbol{k N})\end{array}$ & $\begin{array}{c}\boldsymbol{F y} \\
(\boldsymbol{k N})\end{array}$ & $\begin{array}{c}\boldsymbol{F z} \\
(\boldsymbol{k N})\end{array}$ \\
\hline$T H$ & 128604.17 & 74.024 & - \\
\hline
\end{tabular}

From the comparison of Table 5. and Table 6. it can be seen that the LRB property number 4 is the LRB property which has the greatest reduction in the base shear of $67426,242 \mathrm{kN}$ with a displacement of $150,677 \mathrm{~mm}$, which is still below the maximum displacement, so the LRB property number 4 will be used for further analysis. 
International Journal of Advances in Scientific Research and Engineering (ijasre), Vol 6 (6), June -2020

\subsection{DYNAMIC RESPONSE OF BRIDGE STRUCTURES}
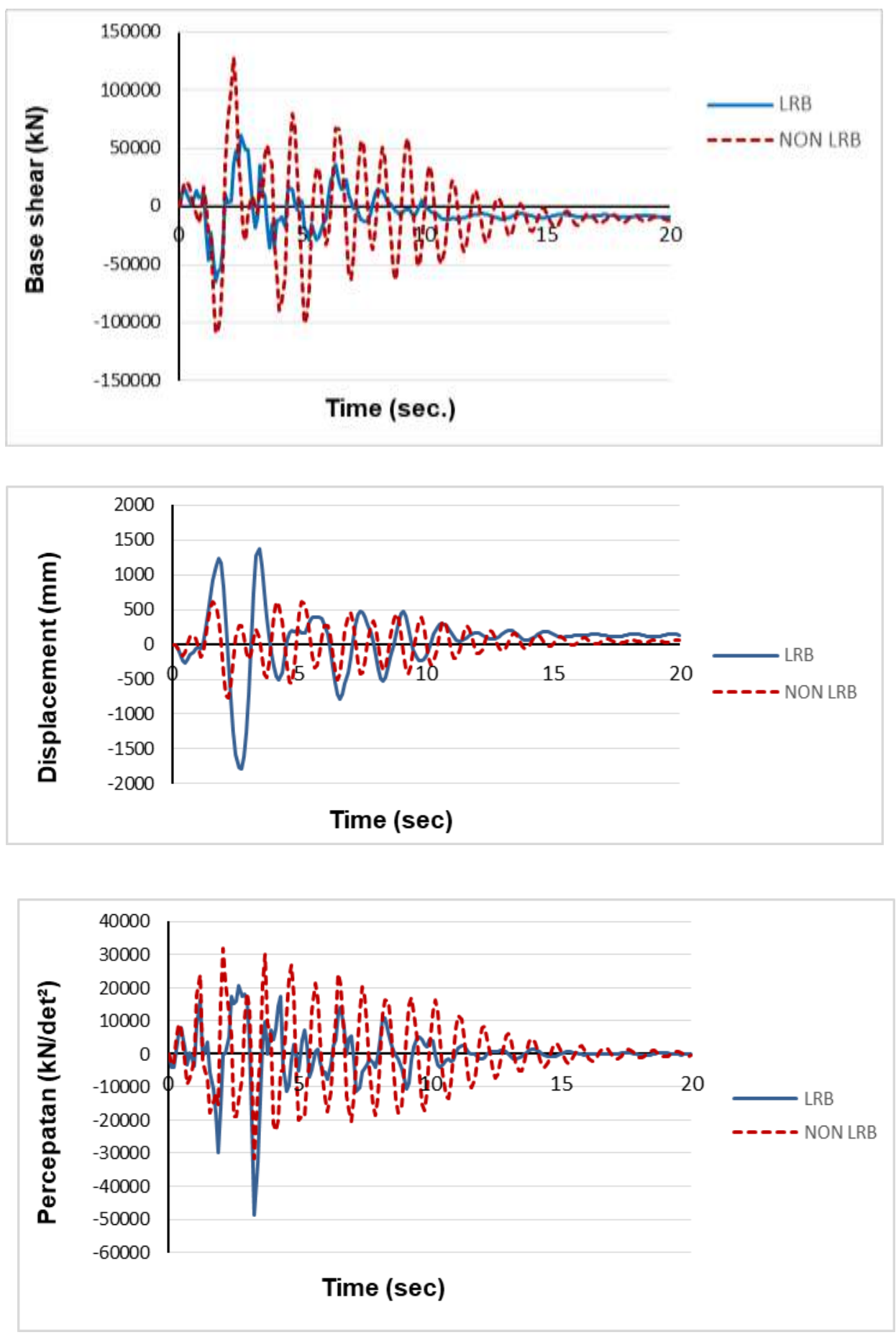

Figure 6. Graph of dynamic response of bridge structures

In Figure 6, It can be seen that the dynamic response of the bridge structure to seismic loads is illustrated by the relationship between the base shear on the bridge pier, bridge deck displacement, and the bridge deck acceleration to the function of time under conditions with LRB and non-LRB, where the results of the modeling show that the use of LRB can reduce the base shear that occurs at the bridge pier but causes the displacement and acceleration that occurs on the bridge deck to increase. The use of LRB is able to reduce the base shear that occurs on the bridge pier by $49.21 \%$ but causes displacement on the bridge deck to increase by 1.33 times and acceleration on the bridge deck to increase by 0.49 times that of the bridge non-LRB. This result is smaller than the results of research from Haque et al. 2010, which compared the conditions non-isolated with HDRB, LRB, and $\mathrm{RB}$ conditions on the highway bridge. The research result found that, the use of LRB can reduce the base shear that occurred on the bridge pier by $73.52 \%$ but caused an increase in displacement on the bridge deck 2.88 times and the acceleration on the bridge deck is 1.57 times that of the condition non-isolated. 


\subsection{CONCLUSION}

Based on the results of the modeling and analysis that have been done, it can be concluded that the results of this study and previous studies show that the use of LRB is very effective in reducing base shear that occurs but causes additional displacement, and acceleration that occurs on bridges due to seismic loads where the amount is strongly influenced by the stiffnes of the bridge piers.

\section{REFERENCES}

1. Abrahamson NA. 1992. Non-stationary spectral matching Seismological Research Letters

2. Dezfuli F. H., Li S., Alam M. S., Wang J. Q., 2017. Effect of constitutive models on the seismic response of an SMALRB isolated highway bridge

3. Fokhrel A., Li J., Li Y.,Maksis N., Yu Y., 2016. Comparative studies of base isolation syastems featured with lead rubber bearings and friction pendulum bearings.

4. Freyssinet, 2017. Earthquake Protection Devices ISOSISM® Range Catalog

5. Hancock J, Watson-Lamprey J, Abrahamson NA, Bommer JJ, Markatis A, McCoy E, Mendis R. 2006. An improved method of matching response spectra of recorded earthquake ground motion using wavelets. Journal of Earthquake Engineering

6. Himeno T, 2018. Seismic isolation of bridge : devices, common practices on Japan, and examples of application

7. M. N. Haque, A. R. Bhuiyan and M. J. Alam, 2010. Seismic response analysis of base isolated highway bridge: Effectiveness of using laminated rubber bearings

8. Nuraini S., Tambusay A., and Suprobo P., 2018. A comparative study of base isolation devices in light rail transit structure featured with lead rubber bearing and friction pendulum system

9. Park R. dan Hamza M. F., 2016. Earthquake Resistant Structures

10. Samanta A. and Pandey P. 2017. Effect of ground motion modification methods and ground motion duration on seismic performance of A 15-Storied Building. 